\title{
Cisza i milczenie: aktualność propozycji chrześcijańskiej
}

Do najbardziej wyróżniających w stosunku do przeszłości cech współczesnego, technologicznie wysoko zaawansowanego społeczeństwa należy rozwój i wieloaspektowe oddziaływanie środków przekazu informacji ${ }^{1}$. W związku z tym społeczność ludzka bywa określana mianem „społeczeństwa medialnego” lub „społeczeństwa cyfrowego"2. Już pobieżna obserwacja prowadzi do wniosku, iż w jego przypadku mamy do czynienia z dużą ilością, wręcz natłokiem docierających w ten sposób do ludzi różnorakich danych ${ }^{3}$. Na obchodzony 20 maja 2012 roku XLVI Światowy Dzień Środków Społecznego Przekazu papież Benedykt XVI wystosował orędzie pt. Milczenie $i$ stowo droga ewangelizacji ${ }^{4}$. Ukierunkowuje ono, by zastanowić się nad aktualnością chrześcijańskiego podejścia do milczenia i tym samym ciszy dla współczesnego społeczeństwa.

\section{Znaczenie milczenia i ciszy: podejście duchowości chrześcijańskiej}

Terminy „milczenie” i „cisza” nie są synonimami. Wskazują one zarazem na rzeczywistości powiązane ze sobą. Ten związek ilustruje następujący przykład.

\footnotetext{
${ }^{1}$ Por. J. Kulig, Człowiek wobec naporu mediów. Formowanie do racjonalnego korzystania ze środków społecznej komunikacji, „Sosnowieckie Studia Teologiczne” 11 (2013), s. 86n.

${ }^{2}$ Por. M. Drożdż, Homo communicans - personalistic determinants of communication in the context of the media, [w:] Convergence: media in the future, red. A. Baczyński, M. Drożdż, Kraków 2012, s. 14 n.

${ }^{3}$ Przykładowo można wskazać na rozpowszechnione wśród młodych ludzi odsłuchiwanie muzyki za pomocą słuchawek w czasie jazdy środkami transportu publicznego lub idąc.

${ }^{4}$ W tekstach orędzi na Światowe Dni Środków Społecznego Przekazu nie zawsze został zastosowany podział na paragrafy i strony (np. brak takiego podziału w tekstach udostępnianych na serwerze watykańskim www.vatican.va). Stąd wynika zastosowana poniżej forma opisów bibliograficznych.
} 
Katechizm Kościoła Katolickiego mówi o pamiętaniu o Bogu „w ciszy miłującej adoracji” ${ }^{5}$ oraz o adoracji jako „pełnym czci milczeniu przed Bogiem”. Katechizm został przygotowany po francusku i najpierw ukazał się w tym właśnie języku: Catéchisme de l'Eglise catholique (Paris 1992). W obu wskazanych paragrafach w wydaniu francuskim występuje słowo „silence”. Podobnie sprawa ma się z wydaniem łacińskim Katechizmu: Catechismus Catholicae Ecclesiae. W numerach 2143 i 2628 znajduje się słowo „silentium”. Zaś orędzie Benedykta XVI Milczenie $i$ stowo droga ewangelizacji w innych językach nosi tytuł: Silence and Word: Path of Evangelization (ang.), Silence et Parole: chemin d'évangélisation (fr.), Stille und Wort: Weg der Evangelisierung (niem.), Silenzio e Parola: cammino di evangelizzazione (wł.), Silêncio e palavra: caminho de evangelização (portug.), Silencio y Palabra: camino de evangelización (hiszp.) ${ }^{8}$.

Zarówno cisza, jak i milczenie należą do pojęć wieloznacznych. Są odnoszone do ważnych i wielorakich doświadczeń ludzkich, które mogą być bardzo trudne. W ten sposób daje o sobie znać: uwaga (por. Pwt 27, 9), głębokie zastanowienie (por. Dz 15,12), obawa przed wypowiedzeniem niewłaściwych słów (por. Ps 39, 2), mądrość (por. Prz 17, 28), rezerwa (por. 1 Sm 10,27), cześć, szacunek (por. Hi 29, 21), lojalność (por. Iz 36, 21), uznanie winy (por. Hi 13, 19), niewiara (por. Est 4, 14), lęk (por. Dz 18, 9), ból (por. Lm 2, 10), doświadczenie niepowodzenia czy zniszczenia (por. Ps 101, 5; 143, 12; Iz 47, 5). Życie manifestuje się m.in. przez milczenie. Podobnie jest ze śmiercią (por. Ps $31,18 n$ ) ${ }^{9}$. W języku polskim stosowane są takie wyrażenia, jak: „,cisza cmentarna”, „,cisza grobowa”, ,złowroga cisza” czy też „bolesne milczenie”, ,grobowe milczenie”, „ponure milczenie”10. Niezabranie głosu może oznaczać, iż dany człowiek czy grupa stają się winni zaniedbania obowiązku, i to także w sprawach ważnych w wymiarze życia osobistego, jak i społecznego ${ }^{11}$. Milczenie i cisza bywają skutkiem pozbawienia wolności, w tym wolności słowa, sumienia i wyznawania wiary, bezsilności, znakiem śmierci. W wypadku radia czy telewizji mogą wynikać z awarii, w przypadku osoby ludzkiej mogą wskazywać

\footnotetext{
${ }^{5}$ Katechizm Kościoła Katolickiego, wyd. II poprawione, Poznań 2002 [dalej: KKK], 2143.

${ }^{6}$ KKK 2628. Por. Jan Paweł II, list apost. Orientale lumen (2 maja 1995), 16.

${ }^{7}$ Dane za: www.vatican.va/archive/ccc/index_it.htm (4.06.2013).

${ }^{8}$ Dane za: www.vatican.va/holy_father/bene-dict_xvi/messages/communications/index_it.htm (14.03.2013).

${ }^{9}$ Dane za: L. Ryken, J. C. Wilhoit, T. Longman, Stownik symboliki biblijnej. Obrazy, symbole, motywy, metafory, figury stylistyczne i gatunki literackie w Piśmie Świętym, Warszawa 2003, s. 518. Por. G. della Croce, Silenzio, [w:] Dizionario enciclopedico di spiritualità, a cura di E. Ancilli, t. 3, Roma 1992, s. 2310n; L. Bouyer, Wprowadzenie do życia duchowego. Zarys teologii ascetycznej i mistycznej, thum. L. Rutowska, Warszawa 1982, s. 37; B. McGinn, Fundamenty mistyki (do V wieku). Obecność Boga. Historia mistyki zachodniochrześcijańskiej, Kraków 2009, s. 257.

${ }^{10}$ S. Skorupka, Stownik frazeologiczny języka polskiego, Warszawa 1985, s. 146, 447.

${ }^{11}$ Por. Jan Paweł II, enc. Centesimus annus (1 maja 1991), 53; KKK 1736; 1853; 2094 („,grzeszenie przez zaniedbanie").
} 
na nieprawidłowe funkcjonowanie organizmu (por. Mt 15, 30n). Cisza i milczenie mogą być postrzegane jako elementy składające się na rzeczywistości wrogie, groźne dla dzisiejszej cywilizacji, niszczące ją. Systemy prawne uzmysławiają, że współczesna cywilizacja za jeden z ideałów oraz fundamentalnych punktów posiada wolność, w tym prawo do wypowiadania się. Jak bardzo podejrzliwie mogą być dziś traktowane milczenie i cisza, obrazuje Internet. Biorąc pod uwagę jakość oraz ilość znajdujących się w nim wypowiedzi, trzeba wyciągnąć wniosek, iż jest on traktowany jako szansa na to, by móc przede wszystkim wyartykułować własny komunikat. Rysujące się w ten sposób podejście do ciszy i milczenia może jest chrześcijaństwu bliższe, niż się to wydaje w pierwszej chwili. Jeśli tak, to mielibyśmy do czynienia z swoistym elementem pomostu między nim i światem współczesnym. Powyżej zostały przywołane teksty biblijne. Otóż znają one i wykorzystują także następujący związek: „Faktem znaczącym jest, że ten sam hebrajski czasownik (użyty np. w Ps 18, 40;101, 5; Lm 3, 53), który znaczy «niszczyć», [...] oznacza również «uciszać»"12. Według Nowego Testamentu milczenie i tym samym cisza mogą być oznaką, wynikiem zniewolenia przez złego ducha. Zaś jedynym sposobem, by taki stan rzeczy zakończyć, jest interwencja samego Boga lub z Jego upoważnienia. „Raz wyrzucał [Jezus] złego ducha u tego, który był niemy. A gdy zły duch wyszedł, niemy zaczął mówić i tłumy były zdumione” (Łk 11, 14; por. też np. Mt 15, 31).

Chrześcijańskie podejście do ciszy i do milczenia dobrze oddają następujące słowa: „Cisza nie oznacza jedynie wykluczenia słów i nie należy jej pojmować wyłącznie w jej wymiarze negatywnym. Cisza nie jest stanem jakiegoś zapomnienia, pustki, nicości (jak to rozumie współczesny ateizm). Natomiast cisza wyróżnia się właśnie przez swój pozytywny charakter: jest koniecznym zachowaniem, by słuchać Boga i przyjąć pochodzący od Niego przekaz, jest witalną atmosferą dla modlitwy i kultu oddawanego Bogu" ${ }^{13}$. Cisza i milczenie są postrzegane jako mogące wnieść w życie wiele dobrego. Chodzi o relacje z Bogiem, czyli o sprawę najwyższej rangi. Będąc bardzo komunikatywnym, ukierunkowanym na kontakt z innymi (por. np. Hbr 1, 1n), Bóg skutecznie posługuje się ciszą czy milczy (por. np. Ps 44, 24; 83, 2; Mt 26, 23n; Mk 14, 61n; J 19, 10) ${ }^{14}$. Człowiek może oceniać, że Bóg milczy, czyli że nie ma z Nim kontaktu, co staje się dla tegoż człowieka przyczyną cierpienia. Taka ocena może wynikać m.in. z tego, iż dana osoba sama cierpi bądź jest świadkiem cierpienia innych ${ }^{15}$. Jednak należy patrzeć tu o wiele szerzej. Na znaczenie milczenia jako skutecznego Bożego narzędzia zbawczego

${ }^{12}$ L. Ryken, J. C. Wilhoit, T. Longman, Stownik symboliki biblijnej..., dz. cyt., s. 518.

${ }^{13}$ G. della Croce, Silenzio..., dz. cyt., s. 2308.

${ }^{14}$ Por. Benedykt XVI, adhort. apost. Verbum Domini (30 września 2010), 21.

${ }^{15}$ Por. S. Grabska, Cierpienie, [w:] Stownik teologiczny, red. A. Zuberbier, Katowice 1998, s. 92n; E. Zastawnik, Apostolski wymiar choroby i cierpienia w życiu oraz nauczaniu Jana Pawła II, Kraków 2012, s. 45. 
i tym samym na jego wartość zwraca uwagę Katechizm Kościoła Katolickiego: „Całe życie Jezusa jest objawieniem Ojca: Jego słowa i czyny, milczenie i cierpienia, sposób bycia i mówienia" ${ }^{16}$. Milczenie tutaj objawia analogicznie jak np. słowa: podobnie jak to ostatnie jest takim z Bożego wyboru, z woli samego Boga. W ten sposób składa się ono na misterium skuteczności łaski Bożej. W milczeniu i tym samym ciszy we wskazanym wyżej znaczeniu jest właściwe coś boskiego, danego przez Boga: pewien nadzwyczajny dynamizm, życiodajność. W Orientale Lumen Jan Paweł II pisze: „Rodzi się w ten sposób to, co nazywamy apofatyzmem Wschodu chrześcijańskiego: im bardziej człowiek wzrasta w znajomości Boga, tym bardziej pojmuje Go jako tajemnicę niedostępną, nieuchwytną w swej istocie. Nie należy tego mylić z niejasnym mistycyzmem, w którym człowiek gubi się w zagadkowej, bezosobowej rzeczywistości. Przeciwnie, chrześcijanie Wschodu zwracają się do Boga jako do Ojca, Syna i Ducha Świętego [...]. Chrześcijanin Wschodu jest [...] świadom, że można nawiązać kontakt z tą rzeczywistością jedynie przyjmując postawę adoracyjnego milczenia, ponieważ u szczytu poznania i doświadczenia Boga znajduje się Jego absolutna transcendencja. Do tego milczenia dochodzi się raczej za pośrednictwem modlitewnego przyswajania sobie Pisma i liturgii, aniżeli poprzez systematyczną medytację"17.

Cisza i milczenie stanowią dar Boga i zarazem są podjęciem tego daru przez człowieka. To dar i odpowiedź witalnie dotyczące nie tylko życia religijnego w ścisłym znaczeniu. Przez ciszę, milczenie wiedzie jeden z nurtów prowadzących do spotkania z Bogiem, do zjednoczenia z Nim, czy nawet będących już takim spotkaniem, komunią. Tym samym posiadają one podstawowe pozytywne znaczenie dla życia ludzkiego jako takiego tak w wymiarze indywidualnym, jak i społecznym: „Wszyscy potrzebujemy tego milczenia przenikniętego obecnością adorowanego Boga; potrzebuje go teologia, aby mogła w pełni rozwinąć swój charakter mądrościowy i duchowy; potrzebuje go modlitwa, aby nigdy nie zapominała, że oglądanie Boga oznacza zejście z góry z obliczem tak promieniującym, iż trzeba je przykryć zasłoną [...], i aby nasze zgromadzenia umiały uczynić miejsce dla obecności Boga, unikając wychwalania samych siebie; potrzebuje go kaznodziejstwo, aby uniknąć złudzenia, że wielomówstwo może przybliżyć do doświadczenia Boga; potrzebuje go ludzki wysiłek, aby zrezygnować z zamykania się w walce bez miłości i przebaczenia. Potrzebuje go wreszcie dzisiejszy, ogłuszony hałasem człowiek, który często nie umie milczeć, gdyż boi się spotkać samego siebie, odsłonić się, doświadczyć pustki, która staje się pytaniem o sens. Wszyscy, wierzący i niewierzący, muszą nauczyć się milczenia, które pozwoli Bogu mówić, kiedy i jak zechce, a nam rozumieć Jego słowo" ${ }^{18}$. Jak daleko ten nurt prowadzi, jak jest cenny, ukazuje także papież

\footnotetext{
${ }^{16}$ KKK 516. Por. Jan Paweł II, adhort. apost. Catechesi tradendae (16 grudnia 1979), 9.

${ }^{17}$ Jan Paweł II, list apost. Orientale lumen, 16.

${ }^{18}$ Tamże, 16.
} 
Benedykt XVI: „Potrzebujemy milczenia, które staje się kontemplacją, pozwalającą nam wejść w milczenie Boga i w ten sposób dotrzeć tam, gdzie rodzi się Słowo, Słowo odkupieńcze"19. Jeśli cisza i milczenie składają się na samą istotę komunikowania, budowania komunii między Bogiem i człowiekiem, to trzeba pamiętać, iż ta komunia jest niemożliwa, jeśli człowiek jednocześnie nie żyje w komunii miłości ze swymi bliźnimi. Jednoznacznie wskazuje na to przykazanie miłości Boga i bliźniego (por. Mt 22, 36n; Łk 10, 25n). Cisza i milczenie mogą być najwyższą formą realizacji przykazania miłości Boga i bliźniego, czyli odpowiedzi na miłość miłością - zarazem będąc formą komunikowania swego stanowiska ${ }^{20}$.

Chrześcijaństwo to religia, która głosi, że bycie chrześcijaninem posiada kluczowe znaczenie, gdy chodzi o relacje z Bogiem, w tym o zbawienie wieczne (por. Mk 16,16). Takie stanowisko warunkuje ocenę przez chrześcijan wyznawania innych religii. Raczej znacznie mniej znane jest, iż zarazem żywi tutaj szacunek, i dotyczy to np. zachowywania milczenia. Oto dwa przykłady. „Kiedy przy okazji ślubów, pogrzebów czy innych uroczystości chrześcijanie i muzułmanie zachowują pełne szacunku milczenie, kiedy inni się modlą, dają świadectwo o tym, co ich łączy, nie ukrywając ani nie wypierając się tego, co ich dzieli” ${ }^{21}$. „Człowiek autentycznie religijny będzie w Azji spotykał się z szacunkiem i ludzie chętnie za nim pójdą. [...] Wyrzeczenie, oderwanie, pokorę, prostotę i milczenie członkowie wszystkich religii uważają tam za wielkie wartości”"22. Cisza i milczenie są więc w sposób jak najbardziej pozytywny właściwe także bytom stworzonym. Przychodzi na myśl, iż w ten sposób składają się one, podobnie jak mowa czy - szerzej - zdolność komunikowania, na stworzenie przez Boga istot ludzkich właśnie na swe podobieństwo (por. np. Rdz 1, 26n; 1, 3n; 2, 19n).

W przypadku chrześcijaństwa nie tylko modlitwa indywidualna (można tu wskazać medytację), ale także wspólnotowa, w tym liturgia, z powodzeniem wykorzystuje słowa śpiewane i recytowane indywidualnie oraz milczenie i ciszę. W przypadku modlitwy wspólnotowej jest to godne uwagi tym bardziej, że przecież wtedy modli się grupa, która chce czynić to razem, pragnie taką modlitwę odczuwać i ją ukazywać w sposób zewnętrznie uchwytny. Także wtedy cisza i milczenie mogą odgrywać istotną rolę. W 1987 roku Jan Paweł II mówił: „dziękuję za uczestnictwo w tej Najświętszej Ofierze, za uczestnictwo wyrażone modlitwą, śpiewem i milczeniem. Bardzo głębokim, modlitewnym milczeniem wielkiej rzeszy. Myślę, że Pan Jezus

\footnotetext{
${ }^{19}$ Benedykt XVI, Eucharistic Concelebration with the members of the International Theological Commission, www.vatican.va/holy_father/benedict_xvi/homilies/2006/documents/hf_benxvi hom_20061006_commissione-teologica_en.html (25.03.2013).

${ }^{20}$ Por. Jan Paweł II, adhort. apost. Ecclesia in Africa (14 kwietnia 1995), 71.

${ }^{21}$ Tenże, Wspólny dialog dla dobra ludzkiej rodziny. Wizyta w meczecie Omajjadów w Damaszku (6.05.2001), 3, www.opoka.org.pl/biblioteka/W/WP/jan pawel ii/przemowienia/syria ommajad 06052001 . html, por. tenże, Discorso ai rappresentanti delle religioni non cristiane, Tokio 24 lutego 1981.

${ }^{22}$ Tenże, adhort. apost. Ecclesia in Asia (6 listopada 1999), 22.
} 
usłyszał i przyjął zarówno słowo, jak śpiew, jak i to nasze wymowne milczenie, którym powiedzieliśmy tak wiele o sobie. Niech do Jego Serca trafi i to słowo, i ta pieśń, i to milczenie, i niech zawsze będzie z nami, i niech zawsze będzie naszą mocą - On, który przez tysiąc lat był mocą Ludu Bożego na całej polskiej ziemi"23. Z chrześcijańskiego punktu widzenia istotne jest i to, że wieczna pełnia życia, przy całej sobie właściwej niewyobrażalności dla pozostających w doczesności (por. 1 Kor 2, 9n), jest ukazywana zarówno jako radosna uczta (por. Iz 25, 6n; Mt 26, 29) czy też wyśpiewywanie Bogu chwały (por. Ap 5, 9; 14, 1n) 24 $^{24}$ jak również jako kontemplacja - oglądanie Boga w ciszy, w milczeniu ${ }^{25}$. Katechizm Kościoła Katolickiego w zespoleniu milczenia - $\mathrm{i}$ tym samym ciszy - $\mathrm{z}$ kontemplacją dostrzega bardzo ważny pomost, który łączy doczesne „teraz” z eschatologicznym ,jutro” stworzenia, z samym Bogiem. „Kontemplacja jest milczeniem, „symbolem świata, który nadchodzi” [...] lub „milczącą miłością" [...]. Słowa w kontemplacji nie mają charakteru [...] dyskursywnego, lecz są niczym iskry, które zapalają ogień miłości. W tym milczeniu [...] Ojciec wypowiada do nas swoje [...] Słowo, które przyjmuje ciało, cierpi, umiera i zmartwychwstaje, a Duch przybrania za synów pozwala nam uczestniczyć w modlitwie Jezusa" ${ }^{26}$. Cisza i milczenie w takim przypadku należą do samego szczytu komunikowania. Ten religijny charakter nobilituje ciszę i milczenie. Zarazem składają się one tutaj na wskazanie, na przeżywanie różnicy między Bogiem i stworzeniami, jak też na jednoczenie przez Boga istot stworzonych z sobą i na tym fundamencie między nimi. ,Adoracja jest zasadniczą postawą człowieka, który uznaje się za [...] stworzenie przed swoim Stwórcą. Wysławia wielkość Pana, który nas stworzył [...], oraz wszechmoc Zbawiciela, który wyzwala nas od zła. Jest uniżeniem się ducha przed „Królem chwały” (Ps 24, 9-10) i pełnym czci milczeniem przed Bogiem [...]. Adoracja trzykroć świętego i miłowanego ponad [...] wszystko Boga napełnia nas pokorą oraz nadaje pewność naszym błaganiom"27.

Jednocześnie jednak chrześcijaństwu właściwe jest przekonanie, iż cisza ani milczenie nie są bytami boskimi. Nie są one w ostatecznym rozrachunku celem same w sobie. Nie posiadają wartości czy skuteczności absolutnej. Tak to ujął doktor Kościoła św. Franciszek Salezy (1567-1622): „Zdarzało się, że w samotności - tak przecież sprzyjającej doskonaleniu się - ludzie utracili doskonałość, natomiast zachowali ją wśród tłumu, który - zdawałoby się - tak bardzo utrudnia

${ }^{23}$ Tenże, Msza św. połączona z udzieleniem święceń prezbiteratu: słowa przed udzieleniem końcowego błogosławieństwa, Lublin 9 czerwca 1987, [w:] Nauczanie Ojca świętego Jana Pawła II, komputerowy zbiór dokumentów papieskich, wersja 1.0, Kraków 1999.

${ }^{24}$ Por. Z. J. Kijas, Średniowieczne obrazy nieba, [w:] Ante Deum stantes, red. S. Koperek, R. Tyrała, Kraków 2002, s. 741n.

${ }^{25}$ G. della Croce, Silenzio..., dz. cyt., s. 2309. Por. J. Finkenzeller, Eschatologia. Podręcznik teologii dogmatycznej, red. W. Beinert, traktat XI, tłum. W. Szymona, Kraków 2000, s. 235n.

${ }^{26}$ KKK 2717.

${ }^{27}$ KKK 2628. 
udoskonalenie się. [...] Gdziekolwiek się znajdujemy, możemy i powinniśmy dążyć do doskonałości”'28. Ciszy i milczenia nie wolno ani demonizować ani absolutyzować ich znaczenia. Nie wolno ich również wyizolowywać czy przeciwstawiać innym wymiarom ludzkiego życia. Ważne uwagi na ten temat zawiera Orędzie na XLVI Światowy Dzień Środków Społecznego Przekazu papieża Benedykta XVI: „pragnę się z wami podzielić niektórymi refleksjami dotyczącymi pewnego aspektu ludzkiego procesu komunikacji, który jest niekiedy zapomniany, pomimo że jest bardzo ważny [...]. Chodzi o relację między milczeniem i słowem: dwoma wymiarami komunikacji, które powinny się równoważyć, następować po sobie i dopełniać, by uzyskać autentyczny dialog i głęboką bliskość między ludźmi. Kiedy słowo i milczenie nawzajem się wykluczają, komunikacja ulega pogorszeniu albo dlatego że powoduje pewne oszołomienie, albo też dlatego, że - przeciwnie - tworzy klimat chłodu; kiedy natomiast milczenie i słowo się wzajemnie dopełniają, komunikacja nabiera wartości i znaczenia"29.

\section{Wybrane cechy współczesnego społeczeństwa w świetle nauczania Benedykta XVI}

Na nauczanie papieża Benedykta XVI składa się m.in. osiem orędzi na Światowe Dni Środków Społecznego Przekazu: 1) Media: sieć komunikowania, komunii i kooperacji $(2006)^{30}$; 2) Dzieci i środki przekazu jako problem wychowawczy $(2007)^{31}$; 3) Szukanie prawdy, by się nia dzielić $(2008)^{32}$; 4) Nowe technologie, nowe relacje. Trzeba rozpowszechniać kulturę szacunku, dialogu i przyjaźni (2009)33; 5) Kapłan i duszpasterstwo w świecie cyfrowym: nowe media w stużbie Stowa $(2010)^{34}$; 6) Nowe

${ }^{28}$ Św. Franciszek Salezy, Wybór pism, thum. J. Rybałt, Warszawa 1956, s. 208.

${ }^{29}$ Benedykt XVI, Milczenie i słowo droga ewangelizacji. Orędzie na XLVI Światowy Dzień Środków Społecznego Przekazu (24 stycznia 2012), www.vatican.va/holy_father/benedict_xvi/ messages/communications/documents/hf_ben-xvi_mes_20120124_46th-world-communicationsday_pl.html31.01.2012.

${ }^{30} \mathrm{~W}$ wersji włoskiej: I media: rete di comunicazione, comunione e cooperazione, www.vatican.va/ holy_father/benedict_xvi/messages/communications/documents/hf_ben-xvi_mes_20060124_40th-world-communications-day_it.html (31.08.2011).

${ }^{31}$ www.opoka.org.pl/biblioteka/W/WP/benedykt_xvi/przemowienia/massmedia2007_24012007. html (31.08.2011).

${ }^{32}$ www.opoka.org.pl/biblioteka/W/WP/benedykt_xvi/przemowienia/massmedia2008_24012008. html (31.08.2011).

${ }^{33}$ www.opoka.org.pl/biblioteka/W/WP/benedykt_xvi/przemowienia/massmedia2009_24012009. html (31.08.2011).

${ }^{34}$ www.opoka.org.pl/biblioteka/W/WP/benedykt_xvi/przemowienia/massmedia2010_24012010. html (31.08.2011). 
technologie komunikacyjne i głoszenie Ewangelii $(2011)^{35}$; 7) Milczenie i słowo droga ewangelizacji $(2012)^{36}$; 8) Sieci społecznościowe: bramy prawdy i wiary, nowe miejsca ewangelizacji (2013) ${ }^{37}$. Teksty te posiadają dla podjętego tematu szczególne znaczenie. Dotyczą tego wymiary współczesnego życia, jakim jest już potężny i nadal wzbierający nurt wielorakiego przekazywania informacji, w tym także za pomocą dźwięków ${ }^{38}$.

Ważnym tematem, w którym można dopatrywać się pewnego motywu przewodniego dla wskazanych orędzi jest zagadnienie wspólnoty, jej cech i budowania. Jednoznacznie mamy do czynienia z troską o wspólnotę pojmowaną jako związki człowieka (ludzi) z Bogiem oraz człowieka (ludzi) z bliźnimi. W ten sposób media przedstawiają się jako związane $\mathrm{z}$ wypełnianiem przykazania miłości Boga i bliźniego. Nie są one widziane jednostronnie, lecz z poczuciem rzeczywistości. Papież dostrzega, iż mamy tutaj do czynienia z zagrożeniami ${ }^{39}$. Jednak przeważa pozytywne postrzeganie mediów jako już faktycznego i zarazem mającego jeszcze dużo do zaoferowania sprzymierzeńca w budowaniu komunii miłości we wskazanych powyżej wymiarach wertykalnym i horyzontalnym ${ }^{40}$, tak w przypadku doczesności, jak i wieczności ${ }^{41}$.

W orędziach na Światowe Dni Środków Społecznego Przekazu papież Benedykt XVI szczególnie zwraca uwagę na następujące kategorie osób: 1) dzieci; 2) duchowni, kapłani. Orędzie z 2007 roku jest poświęcone pierwszej z tych grup, ściślej - pozytywnemu i negatywnemu oddziaływaniu mass mediów na dzieci. Już na początku tego dokumentu odbiorca otrzymuje wskazanie, iż należy uwzględnić dwa komplementarne kierunki działania, formacji. „Temat XLI Światowego Dnia

${ }^{35}$ www.opoka.org.pl/biblioteka/W/WP/benedykt_xvi/przemowienia/massmedia_24012011.html (31.08.2011). Orędzie to jest także znane pod tytułem: Prawda, przepowiadanie i autentyczność życia w erze cyfrowej, www.archpoznan.pl/content/view/1909/107/ (28.03.2011).

${ }^{36}$ www.vatican.va/holy_father/benedict_xvi/messages/communications/documents/hf_ben-xvi_mes_20120124_46th-world-communications-day_pl.html (26.01.2012).

${ }_{37}$ www.vatican.va/holy_father/benedict_xvi/messages/communications/documents/hf_ben-xvi_mes_20130124_47th-world-communications-day_pl.html (5.02.2013).

$\overline{38}$ Por. K. Niewiadomski, Rola komunikacji niewerbalnej podczas sprawowania sakramentu pojednania. Aspekt teologiczno-pastoralny, „Sosnowieckie Studia Teologiczne” 11 (2013), s. 332n; D. G. Leathers, Komunikacja niewerbalna. Zasady i zastosowania, tłum. M. Trzcińska, Warszawa 2007, s. 34n; T. Grove, Niewerbalne elementy interakcji, [w:] Mosty zamiast murów, red. J. Steward, thum. J. Suchecki, Warszawa 2007, s. 122.

${ }^{39}$ Por. np. Benedykt XVI, Dzieci i środki przekazu jako problem wychowawczy, 2, www.opoka. org.pl/biblioteka/W/WP/benedykt_xvi/przemowienia/massmedia2007_24012007.html (31.08.2011).

${ }^{40} \mathrm{Nie}$ oznacza to wyobcowania człowieka w stosunku do innych bytów stworzonych. Bez nich ani jednego, ani drugiego wymiaru komunii nie da się urzeczywistnić. Por. A. Baczyński, Troska o przyrodę troska o człowieka - ekologia w mediach, [w:] Nie lękajcie się. Jan Pawet II i media, red. A. Baczyński, M. Drożdż, Kraków 2011, s. 210n; J. Makowski, Cierniowa korona stworzenia, www.opoka.org.pl/biblioteka/P/PR/tp201051_korona.html (22.05.2013).

${ }^{41}$ Por. Benedykt XVI, Nowe technologie komunikacyjne i głoszenie Ewangelii. 
Środków Społecznego Przekazu: Dzieci i środki przekazu jako problem wychowawczy, pobudza nas do refleksji nad dwoma bardzo istotnymi zagadnieniami, które są ze sobą powiązane. Pierwsze to wychowanie dzieci. Drugie, być może mniej oczywiste, ale nie mniej ważne, to formacja świata mediów"42. Osoba ludzka oraz społeczność są ukazywane jako dynamiczne, zmienne, posiadające możliwość rozwoju. Oznacza to jednak, iż trzeba też liczyć się z zagrożeniami. Na taką sytuację składają się wzajemne oddziaływania. „Występuje tu swoista współzależność, wskazująca na odpowiedzialność mediów jako przedsiębiorstw i potrzebę czynnej i krytycznej postawy czytelników, widzów i słuchaczy. W związku z tym przygotowanie do właściwego korzystania z mediów jest bardzo ważne dla kulturalnego, moralnego i duchowego rozwoju dzieci”" . Papież podkreśla, iż oddziaływanie ze strony mass mediów odgrywa tutaj coraz bardziej znaczącą rolę. „Złożone wyzwania, którym współcześnie musi stawić czoło wychowanie, często są związane z faktem, że w naszym świecie media mają coraz większy wpływ. Jako jeden z aspektów zjawiska globalizacji i owoc szybkiego rozwoju techniki kształtują środowisko kulturowe [...]. Niektórzy twierdzą wręcz, że formacyjny wpływ mediów na wychowanie współzawodniczy z wpływem szkoły, Kościoła, a może nawet rodziny"44. Jest ewidentne, że troska o dzieci jest troską o przyszłość ich samych i, szerzej, świata.

W orędziu Kapłan i duszpasterstwo w świecie cyfrowym: nowe media w slużbie Stowa papież koncentruje uwagę na grupie, na której w szczególny sposób spoczywa zadanie głoszenia Ewangelii. Misję tę mają oni wypełniać także w świecie mediów, poprzez mass media. Papież pisze o tzw. „świecie cyfrowym”. Należy uwzględnić, iż ten „świat” w taki czy inny sposób jest przestrzenią czy też narzędziem także innych mediów (np. przez udostępnianie w Internecie różnych materiałów) ${ }^{45}$. $Z$ takich czy innych względów życie duchownych nieraz kojarzy się z wyciszeniem, samotnością, a ogólniej - ze wszystkim, co znacznie odbiega czy wręcz jest przeciwieństwem świata mediów, w tym także mediów cyfrowych. Już sama formacja do kapłaństwa może być postrzegana jako zmierzająca $\mathrm{w}$ tym kierunku, np. poprzez przestrzeganie okresowego wyciszenia, tzw. ,silentium sacrum". Jednak takie spojrzenie byłoby jednostronne. W poświęconej współczesnym oczekiwaniom wobec formacji ka-

${ }^{42}$ Tenże, Dzieci i środki przekazu jako problem wychowawczy, 1. Por. też niepokojącą ocenę związków między mass mediami i człowiekiem oraz społeczeństwem [w:] L. Boriello, G. della Croce, B. Secondin, Historia duchowości, t. 6, Duchowość chrześcijańska czasów współczesnych, tłum. M. Pierzchała, Kraków 1998, s. 505n.

${ }^{43}$ Tenże, Dzieci i środki przekazu jako problem wychowawczy, 2.

${ }^{44}$ Tenże, Dzieci i środki przekazu jako problem wychowawczy, 1. Por. też Jan Paweł II, Szybki rozwój. List apostolski do odpowiedzialnych za środki społecznego przekazu (24 stycznia 2005), 3, www.opoka.org.pl/biblioteka/W/WP/jan_pawel_ii/listy/szybkir_24022005.html (31.09.2005).

${ }^{45}$ Można tu wymienić elektroniczne wydania czy streszczenia książek, czasopism, nagrania muzyczne, filmy. Na uwagę zasługuje także rozpowszechnione udostępnianie programów radiowych i telewizyjnych on-line. 
płańskiej adhortacji Pastores dabo vobis bł. Jan Paweł II jednoznacznie stwierdza: „Samotność [...] nie jest tylko źródłem trudności, może być bowiem także szansą w życiu kapłana: ,przyjęta w duchu ofiary i poszukiwana w bliskości Pana Jezusa Chrystusa, samotność może być okazją do modlitwy i do studiów, a także pomocą w dążeniu do świętości i ludzkiej dojrzałości" [...]. Nie trzeba przy tym przypominać, że pewna forma samotności jest niezbędnym elementem formacji stałej. [...]. Zdolność wytrwania we właściwego rodzaju samotności jest podstawą troski o życie wewnętrzne. Mowa tu o samotności wypełnionej obecnością Chrystusa, który jest pośrednikiem między nami a Ojcem, w jedności Ducha Świętego. W tym sensie zachowywanie milczenia oraz poszukiwanie przestrzeni i czasu "pustyni” to konieczne elementy stałej formacji w dziedzinie intelektualnej, jak duchowej i duszpasterskiej. W tym samym sensie mówi się także, iż kto nie umie dobrze przeżywać samotności, nie jest zdolny do prawdziwej i braterskiej więzi z innymi”"

Magisterium Ecclesiae zwraca uwagę na przydatność, nawet konieczność ciszy i milczenia. Zarazem wskazuje ono, iż na podstawowe warunki wypełniania przez kapłana posługi głoszenia Ewangelii składa się obecnie wymóg dostrzeżenia świata cyfrowego, skorzystania z szans, jakie on stwarza. „Od księży natomiast wymaga się, by potrafili być obecni w świecie cyfrowym w sposób zawsze wierny przesłaniu ewangelicznemu, by odgrywali właściwą sobie rolę animatorów wspólnot, które w dzisiejszych czasach coraz częściej wyrażają się poprzez różnorodne „głosy”, pochodzące ze świata cyfrowego, i by głosili Ewangelię, wykorzystując oprócz tradycyjnych również audiowizualne środki nowej generacji (zdjęcia, wideo, animacje, blogi, strony internetowe), które stwarzają nieznane dotąd okazje do dialogu i są przydatne także w ewangelizacji i katechezie" ${ }^{47}$. Zaniedbanie głoszenia Ewangelii $\mathrm{w}$ świecie cyfrowym może nawet być przyczyną niedotarcia z nią do wielu ludzi. „Wierzący dostrzegają bowiem coraz bardziej, że jeśli Dobrej Nowiny

${ }^{46}$ Jan Paweł II, adhort. apost. Pastores dabo vobis (25 marca 1992), 74. Dobry przykład stanowi tu informacja umieszczona na portalu Wyższego Seminarium Duchownego w Świdnicy, zakładka Formacja duchowa: „Silentium sacrum, czyli (z łac.) święta cisza, święte milczenie. Silentium obowiązuje kleryków podczas rekolekcji i dni skupienia. Obowiązuje również codziennie po modlitwach wieczornych do zakończenia Eucharystii dnia następnego. Termin silentium doskonale oddaje inna nazwa, która związana jest z życiem ojców pustyni, a mianowicie: «czas pustyni». Otóż ojcowie pustyni odchodzili na miejsca odosobnienia nie tylko po to, aby odpocząć od gwary i szumu codziennej rzeczywistości, ale przed wszystkim po to, aby tak usłyszeć głos Boga. Czas pustyni to kairos, czyli (z gr.) czas łaski potrzebny od odzyskania wewnętrznej wolności i dystansu. To czas potrzebny do budowania relacji z Bogiem, a przez to budowania relacji z ludźmi. To czas do przemodlenia swoich uczuć, emocji, pragnień, lęków, zranień i problemów. Wreszcie to czas duchowego i psychicznego wypoczynku. Tak więc silentium to błogosławiona cisza, wypełniona Bożym pokojem”, www.seminarium.swidnica.pl (22.05.2013). Por. M. Magrassi, Biblia i modlitwa. Lectio divina, thum. B. Żurowska, Kraków 2002, s. 162.

${ }^{47}$ Benedykt XVI, Kapłan i duszpasterstwo w świecie cyfrowym: nowe media w stużbie Stowa. Orędzie na XLIV Światowy Dzień Środków Społecznego Przekazu (24 stycznia 2010). 
nie będzie można poznać także w świecie cyfrowym, to może być ona nieobecna w doświadczeniu wielu osób, dla których ta przestrzeń egzystencjalna jest ważna. Świat cyfrowy nie jest światem paralelnym ani czysto wirtualnym, lecz dla wielu ludzi [...] stanowi część codziennej rzeczywistości"48. Świat mediów cyfrowych, przy całej obfitości informacji, różnorodności przekonań, występowaniu także postaw wrogich chrześcijaństwu czy religii jako takiej, nowości nastawień, sam w sobie nie jest rzeczywistością porzuconą przez Boga czy niedostępną dla Niego. Stanowi on część dzieła stworzenia-zbawienia. Jest przestrzenią i okolicznościami, które potrzebują kapłanów wypełniających swą misję głoszenia Ewangelii. „Także w świecie cyfrowym trzeba ukazać, że pełna miłości Boża troska o nas w Chrystusie to nie przeszłość ani też uczona teoria, lecz bardzo konkretna i aktualna rzeczywistość. Duszpasterstwo w świecie cyfrowym musi umieć pokazać ludziom naszych czasów i zagubionej współczesnej ludzkości, że „Bóg jest blisko, że w Chrystusie nawzajem do siebie należymy" ${ }^{49}$. Przy czym owocna chrześcijańska obecność w świecie cyfrowym jest jednym z elementów globalizacji, należy do warunków, których spełnienie jest konieczne, byśmy rzeczywiście z tą ostatnią mieli do czynienia. „Wyzwaniem, przed którym muszą stanąć sieci społecznościowe, jest to, aby były one rzeczywiście powszechne: wspomagać je będzie wówczas pełny udział wierzących, którzy pragną dzielić się orędziem Jezusa i wartościami godności ludzkiej, które krzewi Jego nauczanie" 50 .

Za podsumowanie nauczania papieża Benedykta XVI na temat mediów można uznać orędzie z 2013 roku Sieci spolecznościowe: bramy prawdy $i$ wiary, nowe miejsca ewangelizacji. Dokument ten zawiera m.in. ważne wskazania dotyczące radzenia sobie z obfitością docierających danych, nieraz nieprzydatnych do niczego. Jednym z narzędzi jest tutaj postawa otwarcia się na innych, pozostawienia im „miejsca” $\mathrm{w}$ wielkim strumieniu medialnym. Polega ona na umiejętnym łączeniu przekazywania danych z powstrzymaniem się od takiego działania, inaczej mówiąc, także na swego rodzaju milczeniu, wyciszeniu się. „Kultura sieci społecznościowych oraz zmiany form i stylów komunikacji stanowią poważne wyzwania dla tych, którzy chcą mówić o prawdzie i wartościach. Często, jak dzieje się to także w przypadku innych środków społecznego przekazu, znaczenie i skuteczność różnych form wypowiedzi zdają się być bardziej określone przez ich popularność niż ich rzeczywistą doniosłość i wiarygodność. [...] Niekiedy dyskretny głos rozsądku może być przytłumiony przez zgiełk zbędnych informacji i nie udaje mu się przyciągnąć uwagi, zastrzeżonej natomiast dla tych, którzy wyrażają się bardziej przekonująco" "51. Zaraz potem papież

${ }^{48}$ Tenże, Sieci społecznościowe: bramy prawdy i wiary, nowe miejsca ewangelizacji. Orędzie na XLVII Światowy Dzień Środków Społecznego Przekazu (24 stycznia 2013).

${ }^{49}$ Tenże, Kapłan i duszpasterstwo w świecie cyfrowym: nowe media w stużbie Stowa.

${ }^{50}$ Tenże, Sieci społecznościowe: bramy prawdy i wiary, nowe miejsca ewangelizacji.

${ }^{51}$ Tamże. 
dodaje: „Media społecznościowe potrzebują zatem zaangażowania wszystkich, którzy są świadomi wartości dialogu, rozsądnej debaty, logicznej argumentacji; osób starających się dbać o te formy wypowiedzi i wyrażania się, które odwołują się do najszlachetniejszych dążeń ludzi zaangażowanych w proces komunikacji. Dialog i debata mogą rozkwitać i wzrastać także wtedy, gdy się rozmawia i traktuje na serio tych, którzy mają poglądy odmienne od naszych"52.

\section{Chrześcijańskie podejście do milczenia i ciszy jako szansa dla społeczeństwa cyfrowego}

Duchowość chrześcijańska od dawna wskazuje na pozytywne znaczenie np. czasowego wyciszenia, milczenia. Celem jest tu zwłaszcza lepsze poznanie woli Bożej i wprowadzanie jej w życie, czyli coraz doskonalsze wypełnianie przykazania miłości Boga i bliźniego ${ }^{53}$. Propozycja ta cieszy się zainteresowaniem także dzisiaj, czyli w społeczności diagnozowanej jako podlegająca silnej dechrystianizacji czy laicyzacji, gdzie nieraz nowoczesność i wyznawanie chrześcijaństwa prezentowane są jako wykluczające się wzajemnie. Oto wybrane dane na ten temat (notabene wskazują one na zainteresowanie ze strony mediów nie tylko kościelnych). „Coraz więcej osób decyduje się na to, by spędzić sylwestra w murach klasztoru z dala od hucznych zabaw, ale za to w ciszy, kontemplacji i modlitwie. Na pomysł zorganizowania ,antysylwestra” wpadli w 2008 roku benedyktyni z Tyńca. Dostrzegli oni, że nie każdy ma ochotę spędzać sylwestra w thumie bawiących się ludzi, a kilkudniowy pobyt w klasztornych murach może stać się kuszącą propozycją dla spragnionych ciszy i odpoczynku od codziennych spraw. Mnisi proponują tym, którzy potrzebują wyciszenia i ascezy, aby przeżyli ostatni dzień starego i pierwszy dzień nowego roku w odosobnieniu” ${ }^{54}$. Oto drugi przykład: „Poza pielgrzymkami wierni coraz chętniej przeznaczają urlop na wyjazdowe formy rekolekcji. Na te ignacjańskie trzeba zapisywać się dużo wcześniej. Nie ma już szans, żeby dostać się w sierpniu. Brakuje miejsc"55. Wskazaną tendencję potwierdzają także słowa: „Ponad 50 waka-

${ }^{52}$ Tamże.

${ }^{53}$ Por. W. Zyzak, Kapłaństwo prezbiterów. Studium nauczania Jana Pawła II, Kraków 2010, s. 351; G. M. Korczak, Szkoła „Jeunesse-Lumière” o. Daniela-Ange. Próba syntezy duchowości, Lublin 2009, s. 174; R. Kimsza, Chrześcijański monastycyzm - jedyna droga przebóstwienia człowieka?, [w:] Misja bułgarska zmartwychwstańców: 150 lat w stużbie Kościołowi i społeczeństwu, red. W. Misztal, W. Mleczko, Kraków 2013, s. 28n.

${ }^{54}$ Brak autora, Coraz więcej chętnych spędza sylwester w klasztorze, www.diecezja.pl/archidiecezja/ aktualnosci/coraz-wiecej-chetnych-spedza-sylwester-w-klasztorze.html (14.03.2013).

${ }^{55}$ Brak autora, Zaczyna brakować miejsc na... wakacyjne rekolekcje, www.wiadomosci.gazeta. pl/wiadomosci/1,114873,10059240,Zaczyna_brakowac_miejsc_na (14.03.2013). wakacyjne_rekolekcje.html 
cyjnych wyjazdów prezentuje na swojej stronie internetowej wspólnota Domowego Kościoła. Przy kilkunastu jest adnotacja „brak miejsc”. „To rekolekcje formacyjne, które przydadzą się w codziennym życiu. Pomagają uczestnikom w konkretnych sytuacjach związanych z małżeństwem czy wychowywaniem dzieci" ${ }^{36}$. Mamy również do czynienia z uznaniem, z nadziejami pokładanymi w związku z tak ważnym i trudnym zagadnieniem, jakim jest resocjalizacja przestępców. „Dziś już wiadomo, że program działa, a zainteresowanie kryminalistów jest ogromne. [...] Pomysłodawcą i realizatorem przedsięwzięcia jest Szwedzka Rada Chrześcijańska odpowiedzialna za opiekę duchową nad przestępcami w zakładach karnych w cały kraju. Skupia ona osoby duchowne różnych wyznań: luterańskich pastorów, katolickich księży, prawosławnych popów, muzułmańskich imamów. [...] Do obligatoryjnych zajęć należy także oddawanie się kilkugodzinnym medytacjom i modlitwom oraz spacer. [...] Zabronione jest oglądanie telewizji i słuchanie radia, jak również towarzyskie odwiedziny. Tylko w niedzielę można czytać korespondencję i rozmawiać przez telefon"s7.

Istnienie i rozwój społeczeństwa cyfrowego wiąże się także z następującym, poważnym i chyba wciąż niezbyt dostrzeganym niebezpieczeństwem. Ludzie są coraz bardziej narażeni na nadobfitość różnych bodźców. Współcześnie zwraca się uwagę na niebezpieczeństwo smogu elektromagnetycznego, elektrosmogu, zanieczyszczeń elektromagnetycznych ${ }^{58}$. W przypadku przekazu medialnego we właściwej mu różnorodności wizualnej i dźwiękowej analogicznie wypada już mówić o swoistym, niebezpiecznym dla ludzi zanieczyszczeniu, a przynajmniej przeciążeniu ${ }^{59}$. W związku z tym papież Benedykt XVI pisze o swego rodzaju bombardowaniu człowieka „odpowiedziami na pytania, których nigdy sobie nie

${ }^{56}$ Brak autora, ,Rzeczpospolita”: kolejki do wakacji z modlitwa, www.wiadomosci.gazeta.pl/ wiadomosci/1,114873,10059193,_Rzeczpolita (14.03.2013).

${ }^{57}$ A. Nowacka-Isaksson, Więzienie po skandynawsku: mnisi żywot, www.archiwum.rp.pl/artykul/ 675739-Wiezienie-po-skandynawsku:-mnisi-zywot.html (10.04.2007).

${ }^{58}$ „W chwili obecnej sztuczne promieniowanie elektromagnetyczne jest największym energetycznym zanieczyszczeniem na Ziemi. O kilka rzędów wielkości przekracza tło naturalne i nie ma takiego miejsca, gdzie by nie występowało. Źródłem promieniowania jest każde urządzenie (każda instalacja), w którym następuje przepływ prądu np. [...] stacje radiowe i telewizyjne, [...] telefony telefonii komórkowej, radiotelefony, CB-radio, urządzenia radiowo-nawigacyjne, urządzenia elektryczne wykorzystywane w domu, itp.”. Wojewódzki Inspektorat Ochrony Środowiska w Warszawie, Źródła promieniowania elektromagnetycznego, www.wios.warszawa.pl/pl/monitoring-srodowiska/ monitoring-pol-elektro/zrodla-promieniowania/78,Zrodla-promieniowania-elektromagnetycznego. html (25.03.2013).

${ }^{59}$ Do odnotowania są tu przypadki ekstremalne, niebezpieczne już na krótką metę. Rozpowszechniają się m.in. tzw. e-narkotyki. „Po zażyciu zabija się pająki wielkości domów, tresuje skorpiony, skacze z mostów, przebija głową sufit. Polscy uczniowie eksperymentują z e-narkotykami. To przewróci twoje życie do góry nogami. Wywoła dezorientację, halucynacje, zmieni osobowość - obiecują twórcy e-narkotyków. Jedna dawka to plik dźwiękowy. Wybór jest spory: można sobie zaaplikować coś, co zadziała jak LSD, haszysz, a nawet pejotl”, M. Święchowicz, współpraca C. Bajka, E-narkotyki, czyli 
stawiał, albo potrzebami, których nie odczuwa" ${ }^{60}$. By uniknąć nieporozumień, należy podkreślić, że nie mamy tutaj do czynienia z jednostronnie negatywną oceną społeczeństwa medialnego i postępu technicznego. Papież Benedykt XVI wskazuje na pewien wymiar duchowy, sakralny i to jako zasadniczy nie tylko w wymiarze religijnym, jaki jest właściwy rozwojowi cywilizacji. „Przekaz w czasach „nowych mediów” pociąga za sobą coraz ściślejszy i bardziej codzienny związek człowieka z urządzeniami, od komputerów do telefonów komórkowych, by wymienić tylko najbardziej rozpowszechnione. Jakie skutki będzie miał ten stały związek?”61. Zaraz potem pada odpowiedź: „Już papież Paweł VI wskazywał kierunek refleksji, gdy mówiąc o pierwszych projektach automatyzacji językowej analizy tekstu biblijnego, zadawał sobie pytanie: „Czyż ten wysiłek nadania narzędziom mechanicznym swoistej funkcji duchowej, który przez swą użyteczność zostaje uszlachetniony i uwznioślony, nie ociera się o sacrum? Czy to duch został uwięziony przez materię, czy może materia, ujarzmiona i zmuszona do posłuszeństwa wobec praw ducha, składa temu duchowi wielki hołd?" (przemówienie w Ośrodku Automatyzacji Aloisianum w Gallarate, 19 czerwca 1964). Wyczuwa się, że słowa te mówią o głębokiej więzi z duchem, która jest powołaniem technologii” ${ }^{2}$. Bł. Jan Paweł II użył nawet określenia „błogosławiona telewizja"63.

Kwestia milczenia, ciszy sytuuje się więc w złożonym kontekście. Trzeba dodać: milczenie i cisza współtworzą czy też winny go współtworzyć jako ważny, pozytywny protagonista. Przedstawiają się jako pomocne w tym, by wydobyć to, co dobre, by kształtować środowisko, w tym otoczenie medialne, w którym żyjemy, tak aby było jak najbardziej przyjazne ludziom. Warto przywołać jeszcze inną, tym razem dużo mniej znaną wypowiedź papieża Benedykta XVI, który wskazuje, iż zasięg zmian jest tak poważny, że można mówić o „mutacji antropologicznej” wywołanej przez rozwój świata cyfrowego: „Coraz bardziej, także nie dostrzegając tego, ludzie pogrążeni są w wymiarze wirtualnym, z powodu przekazów audiowizualnych, które towarzyszą im w życiu od rana do wieczora.

naćpani dźwiękami, www.polska.newsweek.pl/e-narkotyki--czyli-nacpani-dzwiekami,92121,1,1.html (25.03.2013).

${ }^{60}$ Benedykt XVI, Milczenie i stowo droga ewangelizacji. Por. A. Baczyński, New media. The world as a never-ending spectacle, [w:] Convergence: media in the future, dz. cyt., s. 37n.

${ }^{61}$ Tenże, Mówmy ludziom o Bogu, postugując się nowymi językami cyfrowymi. Przemówienie z okazji zgromadzenia plenarnego Papieskiej Rady ds. Środków Społecznego Przekazu (28 lutego 2011), www.opoka.org.pl/biblioteka/W/WP/benedykt_xvi/przemowienia/massmedia_28022011.html (31.08.2011).

${ }^{62}$ Tenże, Mówmy ludziom o Bogu, posługując się nowymi językami cyfrowymi. Por. tenże, enc. Caritas in veritate (29 czerwca 2009), 69.

${ }^{63}$ Por. A. Baczyński, Jan Pawet II - blask osoby w telewizji, [w:] Nie lękajcie się. Jan Pawet II i media, dz. cyt., s. 109. 
Najmłodsi, którzy już urodzili się w tych realiach, wydają się chcieć wypełnić muzyką i obrazem każdy pusty moment, niemal jakby ze strachu przed tą pustką. [...] tendencja ta [...] osiągnęła dzisiaj poziom, który skłania do tego, by mówić o mutacji antropologicznej. Niektórzy ludzie nie są już w stanie pozostać długo w ciszy i samotności. [...] Wycofując się w milczenie i samotność, człowiek [...] „wystawia się" na rzeczywistość w swej nagości, wystawia się na tę pozorną pustkę, którą wskazałem wcześniej, by doświadczyć pełni, obecności Boga, [...] który góruje nad rzeczywistościami uchwytnymi zmysłami" "64. Podobnie nauczał papież Jan Paweł II: „Słuchanie i medytacja karmią się milczeniem. [...] Do ograniczeń społeczeństwa zdominowanego przez technologię i środki masowego przekazu należy również fakt, że milczenie staje się coraz trudniejsze" ${ }^{65}$. Przytoczone słowa pokazują, jak bardzo trzeba wystrzegać się niedostrzegania związków między duchowością i współczesnym wysoko rozwiniętym technologicznie społeczeństwem. Stawkę odrzucenia chrześcijaństwa lub skorzystania z jego duchowości uzmysławiają następujące słowa: „Mózg współczesnego człowieka ma przez tydzień do przetworzenie tyle informacji, ile ludzie sto lat temu przyswajali sobie przez rok. Nasze mózgi nie dają rady. Zmieniają się pod wpływem tych wszystkich bodźców, ewoluują. Nie wiadomo tylko, czy w dobrą stronę i jak to wszystko się skończy. Może być tak, że stres informacyjny doprowadzi nas do zaniku zdolności do koncentracji, zapamiętywania i ukierunkowanego zdeterminowanego działania" ${ }^{\prime 6}$. Wypada w tym miejscu zwrócić uwagę, że duchowość chrześcijańska na negatywny wpływ na człowieka zbyt dużej ilości bodźców zwracała uwagę już w starożytności ${ }^{67}$.

Znaczącym doświadczeniem i wyzwaniem jest wielość informacji docierających zwłaszcza przez Internet, telewizję, radio, prasę. Coraz większy problem stanowi nie tyle zdobycie danych jako takich, ile wyodrębnienie tych prawdziwych i potrzebnych, a następnie ich przyswojenie, wykorzystanie. Pomocne może się tu okazać wyciszenie. Warto zwrócić uwagę na postrzeganie tego zagadnienia w kategoriach ekosystemu, czyli potrzeby uwzględnienia sytuacji w całej jej złożoności: „Tam, gdzie jest dużo wiadomości i informacji, milczenie staje się niezbędne do rozróżnienia tego, co jest ważne, od tego, co jest zbędne lub drugorzędne. Głęboka refleksja pomaga nam odkryć związek istniejący między wydarzeniami [...], ocenić, przeanalizować wiadomości. [...] Z tego względu konieczne jest tworzenie odpowiedniego środowiska,

${ }^{64}$ Benedykt XVI, Omelia: celebrazione dei vespri, Chiesa della Certosa di Serra San Bruno (9 października 2011), hwww.vatican.va/holy_father/benedict_xvi/homilies/2013/documents/hf_ben-xvi_hom_20130125_vespri_it.html (9.10.2011).

${ }^{65}$ Jan Paweł II, List apostolski Rosarium Virginis Mariae (16 października 2002), 31, www.opoka. org.pl/biblioteka/W/WP/jan_pawel_ii/listy/rosarium_virginis_16102002.html (4.06.2013).

${ }^{66}$ W. Eichelberger, Nasz stres powszedni. Rozmowa K. Pawłowskiej-Salińskiej z W. Eichelbergerem, „Gazeta Wyborcza” 13.03.2013, s. 9.

${ }^{67}$ Por. E. Osek, Przyroda w pismach Bazylego Wielkiego, Lublin 2009, 158n. 
pewnego rodzaju „ekosystemu”, który potrafiłby równoważyć milczenie, słowo, obrazy i dźwięki" ${ }^{68}$. Duchowość chrześcijańska, udostępniając swoje, zebrane przez stulecia doświadczenie owocnego sięgania po milczenie i ciszę, przedstawia się jako będąca w stanie odegrać ważną, pozytywną rolę. Nie jest wadą, jeżeli będzie ona związana ze swoistym porządkowaniem życia w wymiarze ziemskim, doczesnym. Skorzystanie z takiej pomocy może odegrać rolę istotnego czynnika, gdy chodzi o radzenie sobie ze współczesnymi uprzedzeniami, obojętnością czy wrogością wobec Kościoła. Nieraz udane, zbawcze spotkanie z Chrystusem w wymiarze nadprzyrodzonym zaczynało się od ustanowienia właściwego stanu rzeczy w wymiarze doczesnym (por. Mt 9, 2; J 9, $1 \mathrm{n}$ ).

W Pastores dabo vobis Jan Paweł II stwierdza m.in.: „Pośród niepokoju i zgiełku panującego w naszym społeczeństwie, koniecznym elementem pedagogii modlitwy jest ukazywanie głębokiego ludzkiego sensu i religijnej wartości milczenia jako atmosfery duchowej nieodzownej do tego, by odczuć obecność Boga i w niej się zanurzyć" ${ }^{69}$. Ze strony chrześcijańskiej mamy propozycję podejście do milczenia, do ciszy w sposób całościowy, zrównoważony. Może ono być pomocą $\mathrm{w}$ formowaniu tak pojedynczych osób, jak też społeczeństwa cyfrowego w jego złożoności: do wsłuchania się w innych, w siebie, do autentycznego dialogu, do takiego komunikowania, które owocuję komunią, wspólnotą. „Milczenie jest integralną częścią komunikacji i bez niego nie ma słów bogatych w treść. W milczeniu słyszymy i poznajemy lepiej samych siebie, rodzi się i pogłębia myśl, z większą jasnością rozumiemy to, co chcemy powiedzieć, albo to, czego oczekujemy od drugiego, dokonujemy wyboru, jak wyrazić siebie. Milknąc pozwalamy drugiej osobie mówić, wyrazić siebie, a sobie samym na to, by nie być przywiązanymi jedynie do naszych słów czy też naszych idei, bez stosownej wymiany myśli. W ten sposób otwiera się przestrzeń wzajemnego słuchania i staje się możliwa pełniejsza relacja międzyludzka" "70. Papież Benedykt XVI zwraca uwagę, że taką pozytywną rolę wyciszenie odgrywa nie tylko, gdy chodzi o szeroko rozumianą wypowiedź ustną. „W milczeniu na przykład rozumie się najbardziej autentyczne elementy komunikacji między tymi, którzy się kochają: gest, wyraz twarzy, ciało, jako znaki, które objawiają osobę. W milczeniu przemawiają radość, zmartwienia, cierpienie, które właśnie w nim znajdują szczególnie intensywną formę wyrazu. Tak więc z milczenia wynika komunikacja jeszcze bardziej wymagająca, przywołująca wrażliwość i tę zdolność słuchania, która często ukazuje miarę i charakter więzi”" Tak więc budowanie wyżej wspomnianego ekosystemu nie oznacza ograniczania

\footnotetext{
${ }^{68}$ Benedykt XVI, Milczenie i słowo droga ewangelizacji.

${ }^{69}$ Jan Paweł II, adhort. apost. Pastores dabo vobis, 36.

${ }^{70}$ Benedykt XVI, Milczenie i słowo droga ewangelizacji.

${ }^{71}$ Tamże.
} 
przekazu, lecz dostosowywanie go do możliwości i potrzeb osoby ludzkiej i tym samym pełniejsze z niego korzystanie.

Proces ten przedstawia się jako korzystny także dla duchowego wymiaru życia ludzkiego, np. gdy chodzi o dzielenie się bogactwem komunii z Bogiem (por. Mt 13, 44n). „W złożonym i zróżnicowanym świecie komunikacji pojawia się jednakże zainteresowanie wielu osób pytaniami ostatecznymi ludzkiej egzystencji: Kim jestem? Co mogę wiedzieć? Co powinienem czynić? Na co mogę mieć nadzieję?"’2. Na chrześcijańską odpowiedź na takie pytania, jak pisze papież Benedykt XVI, składa się, zgodnie ze wskazaną wcześniej prawidłowością, zarówno wypowiedź w wielości sobie właściwych form, jak też cisza. „Ważne jest przyjęcie osób, które formułują te pytania, otwierając możliwość głębokiego dialogu, tworzonego ze słów, wymiany myśli, ale również z zaproszenia do refleksji i milczenia, które czasami może być bardziej wymowne niż pochopna odpowiedź, i pozwala temu, kto stawia sobie pytania, zejść w największą głębię samego siebie i otworzyć się na tę odpowiedź, jaką Bóg wypisał w sercu człowieka"73. W tym kontekście dobrze będzie przywołać dwa przykłady. W roku 2005 odbyła się premiera filmu Die große Stille w reżyserii Philipa Gröninga (w kinach polskich był on wyświetlany jako Wielka cisza). Film pokazuje życie kartuzów w Grande Chartreuse we Francji. Zgodnie z tytułem cechuje go bardzo duża oszczędność w formie. Oprócz śpiewanych przez mnichów psalmów nie pojawia się tam muzyka. Nie ma wywiadów, komentarzy itp. Majestatyczne, godnie dominuje obraz i właśnie cisza. Tę drugą trudno jednak byłoby nazwać np. martwą czy złowrogą. Na zatłoczonym, w niejednym sensie hałaśliwym rynku kina ten film dokumentalny spotkał się z dużym zainteresowaniem i uznaniem. Otrzymał nagrody: Deutsche Filmpreis (2006), Special Jury Prize na Sundance Film Festival (2006), Europejską Nagrodę Filmową w kategorii Film dokumentalny - Prix Arte (2006). W przypadku Wielkiej ciszy mamy do czynienia z dziełem długo i pieczołowicie przygotowywanym. Drugi przykład wiąże się z zaskoczeniem, którego protagonistami przez prawie godzinę stały się rzesze telewidzów. Podczas pielgrzymki do Polski w 2002 roku papież Jan Paweł II nawiedził katedrę wawelską, co telewizja transmitowała na żywo. Otóż niespodziewanie na transmisję złożyła się trwająca ok. 40 minut cisza, kiedy to bł. Jan Paweł II, mistrz słowa i gestu, nieruchomy modlił się w milczeniu ${ }^{74}$. Znana jest opinia, że ze względu na swe cechy i możliwości przekaz filmowy i telewizyjny jest nastawiony na dynamicznie zmieniający się obraz i towarzyszące mu dźwięki ${ }^{75}$. Jak widać, wyciszenie może

\footnotetext{
${ }^{72}$ Tamże.

${ }^{73}$ Tamże.

${ }^{74}$ Szerzej na ten temat zob. A. Baczyński, Jan Pawet II - blask osoby w telewizji..., dz. cyt., s. 112.

${ }^{75}$ Tamże, s. 112.
} 
tutaj dominować nawet przez dłuższy czas i to bez uszczerbku dla przekazu, a wręcz przeciwnie: kreując go czy uzupełniając.

„Doświadczeniem, do którego w naszych wspólnotach należy przywiązywać wielką wagę, jest milczenie. Potrzebujemy go, „aby dać możność wsłuchania się w głos Ducha Świętego przemawiającego do serca, a także by osobistą modlitwę ściślej złączyć ze słowem Bożym i z oficjalną modlitwą Kościoła” [...]. W społeczeństwie, które żyje w coraz większym pośpiechu, niejednokrotnie ogłuszone przez hałas i rozpraszane przez sprawy ulotne, odkrycie wartości milczenia jest kwestią o znaczeniu życiowym. Nieprzypadkowo, także poza chrześcijaństwem, rozpowszechniają się praktyki medytacji, które kładą nacisk na skupienie. Dlaczego więc nie zacząć, z pedagogiczną odwagą, uczyć milczenia, wykorzystując specyfikę doświadczenia chrześcijańskiego? Patrzmy na przykład Jezusa, który „wyszedł z domu i udał się na miejsce pustynne, i tam się modlił" 76 . Człowiek żyjący we współczesnym świecie wysoko rozwiniętych technologii, mający do czynienia z szybkim tempem życia, zmuszony stawiać czoło obfitości bodźców, otrzymuje różne propozycje pomocy, by w takim środowisku móc dobrze funkcjonować ${ }^{77}$. Chrześcijaństwo posiada duże i sprawdzone pod tym względem: dorobek teoretyczny i doświadczenia. Dotyczy to m.in. znaczenia ciszy i milczenia. Być może udostępnianie wspomnianego dorobku teoretycznego i doświadczeń należy postrzegać także jako szansę, by współczesnemu człowiekowi przybliżyć znaczenie życia duchowego i chrześcijaństwa.

\section{Summary}

\section{Quiet and silence: topical proposition of the Christian spirituality}

The article presents the topicality of the Christian approach to the quiet and the silence. Christian spirituality has been characterized by a realistic and balanced treatment of the human person who is a being in need of both quiet and silence, as well as an exchange of information. Then attention

${ }^{76}$ Jan Paweł II, List apostolski w 40. rocznicę ogłoszenia konstytucji soborowej o liturgii świętej Sacrosanctum concilium (4 grudnia 2003), 13, www.opoka.org.pl/biblioteka/W/WP/jan_pawel_ii/ listy/sacrosanctum40_04122003.html (31.07.2011).

${ }^{77}$ Wyszukiwarka Google dla zapytania ,techniki relaksacyjne” podała ok. 249000 wyników wraz sugestią wyszukiwań podobnych: 1) „medytacja”; 2) „proste techniki relaksacyjne”; 3) „techniki relaksacyjne chomikuj”; 4) „techniki relaksacyjne dla dzieci”; 5) „techniki relaksacyjne jacobsona”; 6) „techniki relaksacyjne nerwica”; 7) ,techniki relaksacyjne w przedszkolu”; 8) ,techniki relaksacyjne w walce ze stresem”; dla zapytania „,medytacja relaksacyjna” ok. 116000 wyników oraz jako sugestię dla wyszukiwania zapytania: 1) „medytacja a zdrowie”; 2) „medytacja chrześcijańska”; 3) „,medytacja joga”; 4) „medytacja muzyka”; 5) „,medytacja relaksacyjna chomikuj”; 6) „medytacja relaksacyjna mp3”; 7) „muzyka relaksacyjna”; 8) „relaksacja medytacja”. Dane za: www.google.pl (5.06.2013). 
has been focused on the needs and the potential of contemporary society. In such a context the importance of quiet and silence in case of the contemporary society has been presented as a positively important, even essential element of the fruitful creation of their offer and, subsequently, taking advantage of it.

\section{Keywords}

Christian spirituality, human being, mass media, quiet, silence, social life, spirituality, theology 
